\title{
Forest site conditions and the threat for insect outbreaks in the Scots pine stands of Polissya
}

\author{
Olena Andreieva ${ }^{1} \bowtie$, Anatoliy Goychuk ${ }^{2}$ \\ ${ }^{1}$ Zhytomyr National Agroecological University, Stary Bulv. 7, Zhytomyr, 10008, Ukraine, phone: $+38-0963515130$, \\ e-mail: andreeva-lena15@ukr.net; https://orcid.org/0000-0003-0851-800X \\ ${ }^{2}$ National University of Life and Environmental Science of Ukraine, Heroyiv Oborony st. 15, Kyiv - 03041, Ukraine; \\ https://orcid.org/0000-0003-4773-2148
}

\begin{abstract}
Scots pine (Pinus sylvestris L.) is the most spread forest tree species in Polissya and the most damaged by foliage browsing and stem insects. The aim of this study was to reveal the changes in the distribution of different forest site conditions for 2010-2019 in Scots pine forests of the selected forestry enterprises of Polissya and possible consequences for the spread of foliage browsing insects. Database of Production Association 'Ukrderzhlisproekt' (by 2010 and 2019) was analysed for five State Forest Enterprises (FE) that are located in the Central (Zhytomyr Region) and Western (Rivne and Volyn Regions) Polissya, where the large scale outbreaks of stem pests were registered last decade.

The types of forest site conditions were designated in accordance with the Ukrainian typology. Distribution of the forest area by trophotops and hygrotops was evaluated for the forest-covered area, for Scots pine stands, and for pure Scots pine stands in 2010 and in 2019.

For 2010-2019, the area of all Scots pine forests and its proportion in the forest-covered area has significantly decreased in the most of analysed forest enterprises. The change for 2010-2019 in the distribution both by the trophotops and by hygrotops of the entire forest-covered area, the area of all Scots pine forests and pure pine forests is not statistically significant. However, in assessment year 2019, the proportion of stands in the moist types of forest site conditions slightly increased. It may be the result of the stands' mortality in the driest sites after an outbreak of bark beetles. A greater decrease in the proportion of Scots pine forest area in the dry poor, fresh poor, and dry relatively poor forest site conditions was found in the western direction. Therefore, the noted decrease in the foci areas of foliage browsing insects in Polissya in 2010-2012 compared to the 2000-2002 could be associated with a decrease in the most preferred stands, namely the poorest and driest types of forest site conditions.
\end{abstract}

\section{KeY WORDS}

bark beetles, foliage browsing insects, hygrotop, trophotop 


\section{INTRODUCTION}

Scots pine (Pinus sylvestris L.) is the most spread forest tree species in Polissya (Buzun et al., 2018) and the most damaged by foliage browsing and stem insects (Andreieva et al. 2018, 2019, 2020; Andreieva and Boliukh 2019; Meshkova 2019).

The foci of mass propagation of foliage browsing insects are formed in favourable ecological conditions, among which the most important is the microclimate, the availability of preferred food, and the absence of natural enemies (Kosunen et al. 2017; Hentschel et al. 2018; Meshkova et al. 2019).

The totality of environmental conditions favourable for mass propagation of the most common foliage browsing insects was evaluated by points that take into account the type of forest site conditions, the relative stocking density, the share of the preferred forage species and its age, as well as additional parameters, particularly, the neighbouring clear-cuts (Meshkova 2006, 2009). Rating of forest plots preferences makes it possible to determine the list of subcompartments in which the forming of foci of foliage browsing insects is possible and the total area of their potential foci. At the same time, it was shown that the places of outbreaks are not permanent, as the age of the stands, the relative density of stocking, and the forest cover of neighbouring subcompartments changes due to clear felling in them (for example, Meshkova and Borysenko 2017).

The type of forest site conditions was considered relatively constant (Migunova 1993). Although more than 60 years ago, it was noted that the humidity of habitats and, accordingly, the hygrotop index can change with a change in the groundwater level, in particular, after land drainage by land reclamation (Mikhovich and Fedets 1965).
In the territory of Polissya, the ground waters are shallow, and in the dry years of the last decade, their level has dropped especially dramatically (Anonimous 2019), which affected the supply of water to the roots of trees, their health condition and susceptibility to pest colonization (Meshkova 2019).

Also, the area of stands, suitable for the formation of foci of foliage browsing insects, may change due to the felling of some stands (Andreieva and Boliukh 2019). Sanitary felling is carried out primarily in the most vulnerable stands (Meshkova et al. 2018). In the last decade, in many regions, the health condition of Scots pine (Pinus sylvestris L.) forests has sharply deteriorated due to a change in climate and an increasing anthropogenic load (Shvidenko et al. 2017), which has created conditions for mass propagation of stem pests (Wermelinger et al. 2008; Colombari et al. 2012, 2013; Siitonen 2014; Björkman et al. 2015; Jaime et al. 2019). To minimize the consequences of these outbreaks, repeated selective felling was carried out in the populated stands, which contributed to a decrease in the relative density of stocking, to the further weakening of trees, the formation of the foci of the foliage browsing insects and of stem pests. As a rule, selective sanitary felling in the foci of stem pests is repeated several times, and completed by clear sanitary felling. In connection with the felling of the stands, potentially suitable for foliagebrowsing insects, the foci area in the Zhytomyr region, in particular, considerably decreased in 2010-2012 as compared to 2000-2002 (Andreieva and Boliukh 2019).

The aim of this study was to reveal the changes in the distribution of different forest site conditions for 2010-2019 in Scots pine forests of the selected forestry enterprises of Polissya and possible consequences for the spread of foliage browsing insects.

Table 1. General characteristics of forest-covered area, particularly Scots pine forest area and pure Scots pine forest area in several Forest Enterprises of Polissya (2010 / 2019)

\begin{tabular}{|l|c|c|c|c|c|}
\hline \multicolumn{1}{|c|}{$\begin{array}{c}\text { Forest Enterprise (FE) or Forest } \\
\text { \& Hunting Enterprise (FHE), Region }\end{array}$} & $\begin{array}{c}\text { Latitude } \\
\mathrm{N}\end{array}$ & $\begin{array}{c}\text { Longi-tude } \\
\mathrm{E}\end{array}$ & $\begin{array}{c}\text { Forest covered } \\
\text { area, ha }\end{array}$ & $\begin{array}{c}\text { Area of Scots pine } \\
\text { stands, ha }\end{array}$ & $\begin{array}{c}\text { Area of pure Scots } \\
\text { pine stands, ha }\end{array}$ \\
\hline Korostenske FHE, Zhytomyr Region & $50^{\circ} 37^{\prime}$ & $28^{\circ} 38^{\prime}$ & $28,093.9 / 24,985.0$ & $11,084.3 / 10,045.5$ & $2,709.6 / 2,487.4$ \\
\hline Lugynske FE, Zhytomyr Region & $51^{\circ} 05^{\prime}$ & $28^{\circ} 19^{\prime}$ & $26,385.0 / 26,842.7$ & $13,726.0 / 13,055.8$ & $4,840.2 / 4,897.4$ \\
\hline Bilokorovytske FE, Zhytomyr Region & $51^{\circ} 06^{\prime}$ & $28^{\circ} 01^{\prime}$ & $51,682.5 / 52,196.3$ & $26,998.5 / 26,351.5$ & $7,145.4 / 7,079.2$ \\
\hline Sarnenske FE, Rivne Region & $51^{\circ} 20^{\prime}$ & $26^{\circ} 36^{\prime}$ & $43,088.7 / 42,415.5$ & $30,997.9 / 27,888.8$ & $17,408.6 / 13,319.5$ \\
\hline Volodymyr-Volynske FE, Volyn Region & $5^{\circ}{ }^{\circ} 51^{\prime}$ & $24^{\circ} 19^{\prime}$ & $30,578.6 / 31,851.4$ & $12,691.3 / 12,721.1$ & $5,069.7 / 5,119.3$ \\
\hline
\end{tabular}

Notes: Latitude and longitude for each forest enterprise were evaluated as centroids of respective contours of the territory using MapInfo Mapping Package 


\section{MATERIAL AND METHODS}

Database of Production Association 'Ukrderzhlisproekt' (by 2010 and 2019) was analysed for four State Forest Enterprises (FE) and Korostenske Forest \& Hunting Enterprise (Korostenske FHE), which are located in the Central (Zhytomyr Region) and Western (Rivne and Volyn Regions) Polissya, where the large scale outbreaks of stem pests were registered last decade with an area of clear sanitary felling from 50 to 270 hectares per year.

The territory covers from $50^{\circ} 37^{\prime} \mathrm{N}$ (Korostenske FHE) to $51^{\circ} 20^{\prime} \mathrm{N}$ (Sarnenske FE), and from $24^{\circ} 19^{\prime} \mathrm{E}$ (Volodymyr-Volynske FE) to $28^{\circ} 38^{\prime}$ E (Korostenske FHE) (Tab. 1).

The types of forest site conditions were designated in accordance with the Ukrainian typology (Migunova 1993). Each forest sub-compartment is characterized by a combination of levels of soil richness (nutritional richness for trees): A, B, C, D; and humidity: 0, 1, 2, 3, 4, 5. These signs are combined in the typological grid of forest site conditions.

The steps of the so-called 'trophogenic' row characterize the subcompartments with a similar level of soil richness (so-called trophotops) and take into account the demands of tree species to soil richness. Like that, for group A ('bor') sandy soils and oligotrophic vegetation (pine, birch) are characteristic; for group B ('subor') sandy loam ('supes') soils and mesotrophic vegetation (Quercus robur, Populus tremulae, Picea abies) in the second layer are peculiar. For group C (so-called 'sugrud'), loamy soils ('suglinok') and megatrophic vegetation (Acer platanoides, for example) are peculiar, and for group D (so-called 'grud'), clay soils, the best growth of mesotrophic and megatrophic vegetation and absence of oligotrophic plants (Pinus sylvestris, for example) are characteristic. By humidity 6 , hygrotops are determined: 0 - very dry, 1 - dry, 2 - fresh, 3 - moist, 4 - damp and 5 - wet, or swamps (Migunova 1993).

The name of each forest site conditions consists of the name of hygrotop and trophotop, for example, $\mathrm{B}_{2}$ - fresh relatively poor forest site conditions; $\mathrm{B}_{3}$ - moist relatively poor forest site conditions; $\mathrm{C}_{2}-$ fresh relatively fertile forest site conditions; $\mathrm{C}_{3}-$ moist relatively fertile forest site conditions (Migunova 1993).

When analysing the database of forest inventory for each forest enterprise, the distribution of the forest area by trophotops and hygrotops was evaluated for the whole forest-covered area, for all Scots pine stands, and for pure Scots pine stands in 2010 and in 2019.

The area of forest stands in particular types of forest site conditions was favourable for foliage browsing insects $\left(A_{1}, A_{2}, A_{1}+A_{2}+B_{1}\right)$ (Meshkova, Borysenko, 2017), and the difference for 2010-2019 was also calculated.

Coordinates for each forest enterprise were evaluated as centroids of respective contours of the territory using MapInfo Mapping Package.

One-way analysis of variance (ANOVA) and $\chi^{2}$ test with a significance level of $p<0.05$ were performed using Microsoft Excel software and statistical software package PAST: Paleontological Statistics Software Package for Education and Data Analysis (Hammer et al. 2001).

\section{Results}

In 2010-2019, the forest-covered area increased in three considered forest enterprises (Lugynske FE, Bilokorovytske FE, Volodymyr-Volynske FE) and decreased in two forest enterprises (Korostenske FHE, Sarnenske FE) (Tab. 2).

At the same time, the area of Scots pine forests decreased in four enterprises and slightly increased in one (Volodymyr-Volynske FE). In Volodymyr-Volynske FE, an increase in the area of Scots pine forests by $29.8 \mathrm{hec}-$ tares occurred with the increase in the area by 1272.8 hectares.

The area of pure Scots pine stands increased only in Lugynske and Volodymyr-Volynske FE and decreased in other Forest Enterprises, and mostly in Sarnenske FE (for 4089.1 ha). The proportion of Scots pine area from the forest-covered area in 2010-2019 in most of the analysed forestry enterprises has decreased, but only in the Korostenske FHE, it has increased. Such changes are significant in all the analysed Forest Enterprises, except Korostenske FHE (see Tab. 2). The proportion of the area of pure Scots pine stands of the area of all Scots pine stands increased in four forest enterprises and decreased in the Sarnenske FE. The increase was significant in Lugynske FE and decrease in Sarnenske FE (see Tab. 2).

In the forest-covered area of the analysed forest enterprises, little has changed in 2010-2019 (Tab. 3). Relatively poor forest site conditions prevail in Bilokorovytske FE and Sarnenske FE; relatively poor and relatively fertile forest site conditions are presented equally in 
Table 2. Change in forest-covered area, proportion of Scots pine stands and pure Scots pine stands over the period 2010-2019 in several Forest Enterprises of Polissya

\begin{tabular}{|c|c|c|c|c|c|}
\hline \multirow[b]{2}{*}{$\begin{array}{c}\text { Forest Enterprise (FE) or Forest } \\
\& \text { Hunting Enterprise (FHE), Region }\end{array}$} & \multicolumn{3}{|c|}{ Change of area for 2010-2019, ha } & \multicolumn{2}{|c|}{ Proportion, \% (2010/2019) } \\
\hline & $\begin{array}{c}\text { forest } \\
\text { covered }\end{array}$ & $\begin{array}{l}\text { Scots pine } \\
\text { stands }\end{array}$ & $\begin{array}{l}\text { pure Scots } \\
\text { pine stands }\end{array}$ & $\begin{array}{l}\text { Scots pine stands } \\
\text { area from forest- } \\
\text { covered area }\end{array}$ & $\begin{array}{l}\text { pure Scots pine stands } \\
\text { area from all Scots pine } \\
\text { stands area }\end{array}$ \\
\hline Korostenske FHE, Zhytomyr Region & $-3,108.9$ & $-1,038.8$ & -222.2 & $39.5 / 40.2$ & $24.4 / 24.8$ \\
\hline Lugynske FE, Zhytomyr Region & 457.7 & -670.2 & 57.2 & $52.0 / 48.6^{*}$ & $35.3 / 37.5^{*}$ \\
\hline Bilokorovytske FE, Zhytomyr Region & 513.8 & -647.0 & -66.2 & $52.2 / 50.5^{*}$ & $26.5 / 26.9$ \\
\hline Sarnenske FE, Rivne Region & -673.2 & $-3,109.1$ & $-4,089.1$ & $71.9 / 65.8^{*}$ & $56.2 / 47.8^{*}$ \\
\hline Volodymyr-Volynske FE, Volyn Region & $1,272.8$ & 29.8 & 49.6 & $41.5 / 39.9^{*}$ & $39.9 / 40.2$ \\
\hline
\end{tabular}

Note: *significant change at $\mathrm{P}<0.001$.

Table 3. Distribution of forest-covered area in several Forest Enterprises of Polissya by trophotops and mean weighted trophotop index $(2010 / 2019)^{*}$

\begin{tabular}{|l|c|c|c|c|c|c|}
\hline \multirow{2}{*}{$\begin{array}{c}\text { Forest Enterprise (FE) or Forest } \\
\text { \& Hunting Enterprise (FHE), Region }\end{array}$} & \multicolumn{4}{|c|}{ Distribution, \% } & Weighted \\
\cline { 2 - 6 } & $\mathrm{A}-$ poor & $\begin{array}{c}\mathrm{B}-\text { relatively } \\
\text { poor }\end{array}$ & $\begin{array}{c}\mathrm{B}-\text { relatively } \\
\text { poor }\end{array}$ & $\mathrm{D}-$ fertile & $\begin{array}{c}\text { trophotop } \\
\text { index }\end{array}$ & $\chi^{2 * *}$ \\
\hline Korostenske FHE, Zhytomyr Region & $8.7 / 9.4$ & $30.7 / 29.6$ & $60.6 / 61.0$ & $0.0 / 0.0$ & B.5/B.5 & 0.10 \\
\hline Lugynske FE, Zhytomyr Region & $11.9 / 11.6$ & $43.3 / 42.2$ & $43.6 / 45.0$ & $1.2 / 1.2$ & B.3/B.4 & 0.10 \\
\hline Bilokorovytske FE, Zhytomyr Region & $8.1 / 7.5$ & $58.3 / 58.0$ & $33.2 / 34.1$ & $0.4 / 0.4$ & B.3/B.3 & 0.10 \\
\hline Sarnenske FE, Rivne Region & $27.2 / 27.0$ & $53.5 / 53.8$ & $19.2 / 19.2$ & $0.1 / 0.0$ & A.9/A.9 & 0.01 \\
\hline Volodymyr-Volynske FE, Volyn Region & $1.3 / 0.9$ & $20.2 / 20.5$ & $64.3 / 68.2$ & $14.2 / 10.4$ & B.9/B.9 & 0.40 \\
\hline
\end{tabular}

Note: *by Ukrainian forest typology (Migunova 1993); $* * \chi_{0.05}^{2}=7.89$ at $\mathrm{df}=3$.

Lugynske FE, and relatively fertile forest site conditions prevail in Korostenske FHE and Volodymyr-Volynske FE. Fertile forest site conditions are presented in a very small area, mostly in Volodymyr-Volynske FE (see Tab. 3). Weighted trophotop index value is the smallest in Sarnenske FE (A.9), the highest in VolodymyrVolynske FE (B.9) with a slight increase for 2010-2019 in Lugynske FE.

The distribution of Scots pine forest area is shifted towards poor conditions compared to the distribution of forested area (Tab. 4). Pine forests prevail in relatively poor forest site conditions in all the considered forest enterprises, except for Volodymyr-Volynske FE, where half of the Scots pine forests are located in relatively fertile forest site conditions. In 2010-2019, changes in the distribution of Scots pine stands by trophotops in most forest enterprises are insignificant.

Pure pine stands occupy more than $50 \%$ in relatively poor forest site conditions in all the analysed for- est enterprises, except Volodymyr-Volynske FE, where their proportion is very close in relatively poor and relatively fertile forest site conditions; moreover, it decreased in relatively fertile forest site conditions in 2019 (42.9\%) compared to 2010 (47.5\%) (Tab. 5). Poor site conditions are in the 2nd place in Lugynske FE, Sarnenske FE and Bilokorovytske FE. In Korostenske FHE, poor Scots pine stands in poor and relatively poor forest site conditions were $15-20.4 \%$ and $17.3-18.4 \%$ in 2010 and 2019 respectively (see Tab. 5).

The change for 2010-2019 in the distribution of the trophotops of the entire forested area, the area of Scots pine forests, and pure pine forests is not statistically significant (see Tab. 3-5).

The analysis of the distribution of the forested area of the considered forestry enterprises by hygrotops indicates the predominance of fresh and moist site conditions (Tab. 6). At the same time, only in VolodymyrVolynske FE, the proportion of the fresh site conditions 
Table 4. Distribution of Scots pine stands' area in several Forest Enterprises of Polissya by trophotops and mean weighted trophotop index $(2010 / 2019)^{*}$

\begin{tabular}{|c|c|c|c|c|c|c|}
\hline \multirow{2}{*}{$\begin{array}{c}\text { Forest Enterprise (FE) or Forest } \\
\& \text { Hunting Enterprise (FHE), Region }\end{array}$} & \multicolumn{4}{|c|}{ Distribution, $\%$} & \multirow{2}{*}{$\begin{array}{l}\text { Weighted } \\
\text { trophotop } \\
\text { index }\end{array}$} & \multirow[b]{2}{*}{$\chi^{2 * *}$} \\
\hline & $\mathrm{A}-$ poor & $\begin{array}{l}\mathrm{B}-\text { relatively } \\
\text { poor }\end{array}$ & $\begin{array}{l}\mathrm{B}-\text { relatively } \\
\text { poor }\end{array}$ & $D$ - fertile & & \\
\hline Korostenske FHE, Zhytomyr Region & $12.3 / 13.5$ & $56.8 / 55.8$ & $30.9 / 30.7$ & $0.0 / 0.0$ & B.2/B.2 & 0.1 \\
\hline Lugynske FE, Zhytomyr Region & $22.4 / 23.3$ & $63.0 / 61.1$ & $14.6 / 15.6$ & $0.0 / 0.0$ & A.9/A.9 & 0.2 \\
\hline Bilokorovytske FE, Zhytomyr Region & $13.8 / 13.3$ & $79.0 / 78.0$ & $7.2 / 8.7$ & $0.0 / 0.0$ & A.9/B.0 & 0.3 \\
\hline Sarnenske FE, Rivne Region & $36.4 / 31.6$ & $59.5 / 63.0$ & $4.1 / 5.4$ & $0.0 / 0.0$ & A.7/A.7 & 1.3 \\
\hline Volodymyr-Volynske FE, Volyn Region & $2.9 / 1.9$ & $41.0 / 40.8$ & $50.5 / 52.2$ & $5.6 / 5.1$ & B.6/B.6 & 0.4 \\
\hline
\end{tabular}

Note: *by Ukrainian forest typology (Migunova 1993); ** $\chi_{0.05}^{2}=7.89$ at $\mathrm{df}=3$.

Table 5. Distribution of pure Scots pine stands' area in several Forest Enterprises of Polissya by trophotops and mean weighted trophotop index $(2010 / 2019)^{*}$

\begin{tabular}{|c|c|c|c|c|c|c|}
\hline \multirow{2}{*}{$\begin{array}{l}\text { Forest Enterprise (FE) or Forest \& } \\
\text { Hunting Enterprise (FHE), Region }\end{array}$} & \multicolumn{4}{|c|}{ Distribution, $\%$} & \multirow{2}{*}{$\begin{array}{l}\text { Weighted } \\
\text { trophotop } \\
\text { index }\end{array}$} & \multirow[b]{2}{*}{$\chi^{2 * *}$} \\
\hline & A - poor & $\begin{array}{l}\mathrm{B}-\underset{\text { poor }}{\text { relatively }} \\
\quad\end{array}$ & $\begin{array}{l}\mathrm{B}-\text { relatively } \\
\text { poor }\end{array}$ & $\mathrm{D}$ - fertile & & \\
\hline Korostenske FHE, Zhytomyr Region & $15.0 / 17.3$ & $64.6 / 64.3$ & $20.4 / 18.4$ & $0.0 / 0.0$ & B.1/B.0 & 0.6 \\
\hline Lugynske FE, Zhytomyr Region & $38.4 / 45.0$ & $54.7 / 49.8$ & $6.9 / 5.2$ & $0.0 / 0.0$ & A.7/A.6 & 2,0 \\
\hline Bilokorovytske FE, Zhytomyr Region & $26.4 / 27.4$ & $71.4 / 70.8$ & $2.2 / 1.7$ & $0.0 / 0.0$ & A.8/A.7 & 0.2 \\
\hline Sarnenske FE, Rivne Region & $45.6 / 43.2$ & $52.2 / 54.2$ & $2.2 / 2.6$ & $0.0 / 0.0$ & A.6/A.6 & 0.3 \\
\hline Volodymyr-Volynske FE, Volyn Region & $4.1 / 2.8$ & $47.1 / 53.7$ & $47.5 / 42.9$ & $1.3 / 0.6$ & B.5/B.4 & 1.8 \\
\hline
\end{tabular}

Note: *by Ukrainian forest typology (Migunova 1993); ${ }^{* *} \chi_{0.05}^{2}=7.89$ at $\mathrm{df}=3$.

Table 6. Distribution of forest-covered area in several Forest Enterprises of Polissya by hygrotops and weighted hygrotop index $(2010 / 2019)^{*}$

\begin{tabular}{|l|c|c|c|c|c|c|c|}
\hline \multirow{2}{*}{$\begin{array}{c}\text { Forest Enterprise (FE) or Forest } \\
\text { \& Hunting Enterprise (FHE), Region }\end{array}$} & \multicolumn{4}{|c|}{ Distribution, \% } & Weighted \\
\cline { 2 - 8 } & $1-$ dry & $2-$ fresh & $3-$ moist & $4-$ damp & $5-$ wet & $\chi^{2 * *}$ \\
\hline Korostenske FHE, Zhytomyr Region & $1.2 / 1.4$ & $35.9 / 34.9$ & $57.4 / 56.5$ & $4.5 / 6.2$ & $1.0 / 1.0$ & $2.6 / 2.7$ & 0.7 \\
\hline Lugynske FE, Zhytomyr Region & $1.0 / 1.0$ & $31.0 / 28.7$ & $52.8 / 54.2$ & $12.2 / 14.3$ & $3.0 / 1.8$ & $2.7 / 2.8$ & 1.1 \\
\hline Bilokorovytske FE, Zhytomyr Region & $0.4 / 0.3$ & $26.2 / 23.0$ & $48.4 / 49.6$ & $18.2 / 19.3$ & $6.8 / 7.8$ & $2.7 / 2.7$ & 0.7 \\
\hline Sarnenske FE, Rivne Region & $6.8 / 6.3$ & $30.2 / 29.7$ & $34.1 / 34.2$ & $26.1 / 27.0$ & $2.8 / 2.8$ & $2.7 / 2.8$ & 0.1 \\
\hline Volodymyr-Volynske FE, Volyn Region & $0.0 / 0.0$ & $49.9 / 48.7$ & $34.9 / 35.8$ & $13.0 / 13.5$ & $2.2 / 2.0$ & $2.6 / 2.6$ & 0.1 \\
\hline
\end{tabular}

Note: *by Ukrainian forest typology (Migunova 1993); ** $\chi_{0.05}^{2}=9.49$ at $\mathrm{df}=4$.

area is greater than the moist ones. In assessment 2019, the proportion of stands in the moist types of forest sites slightly increased, and the proportion of fresh ones decreased comparing to 2010 .

The distribution of the area of Scots pine forests by trophotops shows their predominance in fresh and moist types, and in Volodymyr-Volynske FE, there is almost twice as much in fresh sites as in moist ones. In Korostenske FE and Lugynske FE the area of
Scots pine stands is more in fresh sites, in Bilokorovytske FE and Sarnenske FE is approximately the same (Tab. 7).

Among pure pine stands in Korostenske FHE, Lugynske FE, and Volodymyr-Volynske FE, fresh conditions prevail, where the area is more than 3 times higher than in the moist conditions. In other forest enterprises, the areas of pure pine stands in fresh and moist conditions are very similar (Tab. 8). 
Table 7. Distribution of Scots pine stands' area in several Forest Enterprises of Polissya by hygrotops and weighted hygrotop index $(2010 / 2019)^{*}$

\begin{tabular}{|c|c|c|c|c|c|c|c|}
\hline \multirow{2}{*}{$\begin{array}{c}\text { Forest Enterprise (FE) or Forest } \\
\& \text { Hunting Enterprise (FHE), Region }\end{array}$} & \multicolumn{5}{|c|}{ Distribution, $\%$} & \multirow{2}{*}{$\begin{array}{c}\text { Weighted } \\
\text { hygrotop index }\end{array}$} & \multirow{2}{*}{$\chi^{2 * *}$} \\
\hline & $1-$ dry & $2-$ fresh & $3-$ moist & $4-$ damp & 5 -wet & & \\
\hline Korostenske FHE, Zhytomyr Region & $3.0 / 3.5$ & $52.9 / 52.8$ & $42.0 / 41.1$ & $1.4 / 2.1$ & $0.8 / 0.6$ & $2.4 / 2.4$ & 0.5 \\
\hline Lugynske FE, Zhytomyr Region & $1.9 / 2.0$ & $50.2 / 47.6$ & $40.1 / 42.6$ & $5.3 / 6.3$ & $2.5 / 1.6$ & $2.4 / 2.5$ & 0.8 \\
\hline Bilokorovytske FE, Zhytomyr Region & $0.6 / 0.6$ & $31.7 / 29.4$ & $45.3 / 47.6$ & $14.4 / 13.0$ & $8.1 / 9.4$ & $2.6 / 2.5$ & 0.6 \\
\hline Sarnenske FE, Rivne Region & $9.0 / 6.7$ & $39.7 / 34.6$ & $37.8 / 42.2$ & $12.6 / 15.5$ & $0.9 / 1.0$ & $2.5 / 2.6$ & 2.4 \\
\hline Volodymyr-Volynske FE, Volyn Region & $0.1 / 0.0$ & $62.9 / 62.3$ & $33.0 / 34.0$ & $3.6 / 3.3$ & $0.4 / 0.3$ & $2.4 / 2.4$ & 0.2 \\
\hline
\end{tabular}

Note: *by Ukrainian forest typology (Migunova 1993); ${ }^{* *} \chi^{2}{ }_{0.05}=9.49$ at $\mathrm{df}=4$.

Table 8. Distribution of pure Scots pine stands' area in several Forest Enterprises of Polissya by hygrotops and weighted hygrotop index (2010/2019)*

\begin{tabular}{|l|c|c|c|c|c|c|c|}
\hline \multirow{2}{*}{$\begin{array}{c}\text { Forest Enterprise (FE) or Forest } \\
\text { \& Hunting Enterprise (FHE), Region }\end{array}$} & \multicolumn{4}{c|}{ Distribution, \% } & \multirow{2}{*}{$\begin{array}{c}\text { Weighted } \\
\text { hygrotop index }\end{array}$} & $\chi^{2 * *}$ \\
\cline { 2 - 8 }$n$ & $1-$ dry & $2-$ fresh & $3-$ moist & $4-$ damp & 5 - wet & $2.2 / 2.2$ & 3.6 \\
\hline Korostenske FHE, Zhytomyr Region & $3.4 / 3.8$ & $75.0 / 73.2$ & $20.3 / 21.0$ & $0.3 / 1.3$ & $0.9 / 0.6$ & $2.2 / 2.3$ & 6.4 \\
\hline Lugynske FE, Zhytomyr Region & $3.1 / 3.8$ & $74.4 / 67.5$ & $20.2 / 24.3$ & $1.1 / 3.4$ & $1.1 / 1.0$ & $2.3 / 2.4$ & 2.3 \\
\hline Bilokorovytske FE, Zhytomyr Region & $2.0 / 1.5$ & $38.6 / 31.8$ & $34.8 / 39.1$ & $12.7 / 13.6$ & $11.9 / 14.0$ & $2.4 / 2.5$ & 1.5 \\
\hline Sarnenske FE, Rivne Region & $10.7 / 9.1$ & $47.6 / 43.3$ & $31.1 / 35.8$ & $9.8 / 10.9$ & $0.8 / 0.9$ & 2.9 & 0.7 \\
\hline Volodymyr-Volynske FE, Volyn Region & $0.1 / 0.1$ & $71.6 / 68.0$ & $27.0 / 30.3$ & $1.3 / 1.6$ & $0.0 / 0.0$ & $2.3 / 2.3$ & 0.7 \\
\hline
\end{tabular}

Note: *by Ukrainian forest typology (Migunova 1993); $* * \chi_{0.05}^{2}=9.49$ at $\mathrm{df}=4$.

Table 9. Change for 2010-2019 in the area of Scots pine stands with the type of forest site conditions* favourable for foliage browsing insects in several Forest Enterprises of Polissya

\begin{tabular}{|l|c|c|c|c|}
\hline \multirow{2}{*}{$\begin{array}{c}\text { Forest Enterprise (FE) or Forest } \\
\text { \& Hunting Enterprise (FHE), Region }\end{array}$} & \multicolumn{4}{|c|}{$\begin{array}{c}\text { Change of area, hectares } \\
\text { (numerator }- \text { hectares, denominator }- \text { percent of 2010) }\end{array}$} \\
\cline { 2 - 5 } & dry poor $-\mathrm{A}_{1}$ & fresh poor $-\mathrm{A}_{2}$ & dry relatively poor $-\mathrm{B}_{1}$ & $\mathrm{~A}_{1}+\mathrm{A}_{2}+\mathrm{B}_{1}$ \\
\hline Korostenske FHE, Zhytomyr Region & $19.6 / 6.2$ & $-35.9 /-4.5$ & $-0.9 /-4.3$ & $-17.2 /-1.5$ \\
\hline Lugynske FE, Zhytomyr Region & $2.6 / 1.1$ & $-50.0 /-2.2$ & $-0.7 /-6.4$ & $-48.1 /-1.9$ \\
\hline Bilokorovytske FE, Zhytomyr Region & $-4.5 /-3.3$ & $-114.2 /-8.4$ & $-17.6 /-50.9$ & $-136.3 /-8.9$ \\
\hline Sarnenske FE, Rivne Region & $-908.7 /-32.7$ & $-1,587.5 /-23.8$ & 0 & $-2496.2 /-26.4$ \\
\hline Volodymyr-Volynske FE, Volyn Region & $0.6 /-$ & $-78.9 /-39.1$ & $-2.9 /-40.3$ & $-81.2 /-38.9$ \\
\hline
\end{tabular}

Note: *by Ukrainian forest typology (Migunova 1993).

However, the change for 2010-2019 in the distribution by hygrotops for the entire forested area, the area of Scots pine stands, and pure pine stands is not significant (see Tab. 6-8).

We calculated the changes for 2010-2019 in the area of Scots pine forests (Tab. 9) and pure pine forests (Tab. 10) in certain types of forest site conditions favourable for the formation of foliage browsing insects.

The proportion of Scots pine forest area in the most favourable conditions (dry poor $-\mathrm{A}_{1}$ ) increased over $2010-2019$ by $6.2 \%$ in Korostenske FHE, by $1.1 \%$ in Lugynske FE, did not change in VolodymyrVolynske FE, and decreased in Bilokorovytske FE (by 3.3\%) and Sarnenske FE (by 32.7\%). The share of Scots pine stands in fresh poor $\left(\mathrm{A}_{2}\right)$ and dry relatively poor forest site conditions $\left(\mathrm{B}_{1}\right)$ decreased most of all in Sarnenske FE and Volodymyr-Volynsky FE (see Tab. 9).

The proportion of the area of pure pine stands has increased over 10 years only in the Korostenske FHE 
Table 10. Change for 2010-2019 in the area of pure Scots pine stands with the type of forest site conditions* favourable for foliage browsing insects in several Forest Enterprises of Polissya

\begin{tabular}{|l|c|c|c|c|}
\hline \multirow{2}{*}{$\begin{array}{c}\text { Forest Enterprise (FE) or Forest \& } \\
\text { Hunting Enterprise (FHE), Region }\end{array}$} & \multicolumn{4}{|c|}{$\begin{array}{c}\text { Change of area, hectares } \\
\text { (numerator hectares, denominator percent of 2010) }\end{array}$} \\
\cline { 2 - 5 } & dry poor $-\mathrm{A}_{1}$ & fresh poor $-\mathrm{A}_{2}$ & dry relatively poor $-\mathrm{B}_{1}$ & $\mathrm{~A}_{1}+\mathrm{A}_{2}+\mathrm{B}_{1}$ \\
\hline Korostenske FHE, Zhytomyr Region & $2.3 / 2.5$ & $19.5 / 6.2$ & $0 /-$ & $21.8 / 5.4$ \\
\hline Lugynske FE, Zhytomyr Region & $34.3 / 23.2$ & $202.8 / 13.6$ & $0.6 / 15.0$ & $237.7 / 14.5$ \\
\hline Bilokorovytske FE, Zhytomyr Region & $-25.8 /-21.5$ & $-18.1 /-2.4$ & $-10.9 /-55.3$ & $-54.8 /-6.2$ \\
\hline Sarnenske FE, Rivne Region & $-649.4 /-34.9$ & $-1,502.9 /-29.2$ & 0 & $-2152.3 /-30.7$ \\
\hline Volodymyr-Volynske FE, Volyn Region & $0.6 /-$ & $-48.1 /-36.7$ & $-0.7 /-16.3$ & $-48.2 /-35.6$ \\
\hline
\end{tabular}

Note: *by Ukrainian forest typology (Migunova 1993).

and Lugynsky FE, most of all in fresh poor forest site conditions $-\mathrm{A}_{2}$ (see Tab. 10).

One can note a tendency towards a greater decrease in the proportion of Scots pine forest area in the types of forest site conditions $A_{1}, A_{2}$, and $B_{1}$ in 2019 relative to 2010 in the western direction - as longitude decreases (see Tab. 1, Tab. 9).

\section{Discussion}

Scots pine can grow in a wide range of forest site conditions, but the most productive stands are located in fresh relatively poor and relatively fertile forest site conditions (Migunova 1993). In dry poor and relatively poor forest site conditions, as well as in fresh poor forest site conditions, the pure pine stands most often grow. In more humid hygrotops of poor, relatively poor, relatively fertile, and less often in the fertile trophotops, pine is a part of mixed stands (Buzun et al. 2018).

Among the types of forest site conditions, most foliage browsing insects were proved to prefer the dry poor site conditions $\left(A_{1}\right)$ in a Scots pine forest (very high threat of outbreak) (Meshkova 2009). The threat is very high in dry and fresh poor site conditions $\left(\mathrm{A}_{1}\right.$ and $\mathrm{A}_{2}$ respectively) for common pine sawfly Diprion pini (Linnaeus, 1758) (Hymenoptera: Diprionidae); however, European pine sawfly Neodiprion sertifer (Geoffroy, 1785) (Hymenoptera: Diprionidae) and pine moth Dendrolimus pini (Linnaeus, 1758) (Lepidoptera: Lasiocampidae) can form outbreaks also in dry relatively poor forest site conditions $\left(\mathrm{B}_{1}\right)$ and sometimes in fresh relatively poor forest site conditions $\left(\mathrm{B}_{2}\right)$ (Meshkova 2009).
Engraver pine beetles, Ips acuminatus (Gyllenhal, 1827) and six-toothed bark beetle, Ips sexdentatus (Boerner, 1767) (Curculionidae: Scolytinae) colonize Scots pine stands weakened by any factors in different types of forests (Borodavka et al. 2017; Andreieva et al. 2018, 2019). However, the stands are more often weakened in poorer and drier types of forest site conditions, where they are pure in composition (Meshkova 2019). Therefore, the noted decrease in the foci areas of foliage browsing insects in Polissya in 2010-2012 compared to the 2000-2002 (Andreieva and Boliukh 2019) could be associated with a decrease in the most preferred stands, namely the poorest and driest types of forest site conditions.

The research shows, that the changes of the forestcovered area in some forest enterprises for 2010-2019 (see Tab. 2) are mainly related to changes in the boundaries of certain forest enterprises and the annexation of lands of other users.

The distribution of pure pine stands is most common from a silvicultural point of view in Lugynske FE, Sarnenske FE, and Bilokorovytske FE, where such stands grow in the poorest and driest types of forest site conditions (see Tab. 5). In Korostenske FHE, it is advisable to replace pure pine stands in relatively fertile forest site conditions with mixed ones as much as possible. A large number of pure Scots pine stands in relatively fertile forest site conditions and even in the fertile forest site conditions in Volodymyr-Volynske FE can only be explained by the need to quickly reforest large areas of dried stands in the bark beetle foci.

The decrease in the proportion of Scots pine stands in the driest and poorest types of forest site conditions can be explained by the fact that mostly pure pine 
stands grew there, which were primarily inhabited by bark beetles during the last outbreak, and were largely covered by mortality and clear sanitary felling.

As there were less forest stands in dry hygrotops in the western part of the region (Buzun et al. 2018), the outbreak of bark beetles most reflected in the typological structure of the sites in Sarnenske FE and Volodymyr-Volynske FE.

Since the hygrotop index is directly related to the level of ground water (Migunova 1993; Anonimous 2019), very often the type of forest site conditions in the forest management database does not correspond to the actual one (Borodavka et al. 2017; Orlov personal communication). An indirect confirmation of the decrease in the hygrotop in the territory of Polissya is the forming of foci of pine bark bug (Aradus cinnamomeus Panzer, 1806: Heteroptera: Aradidae) in the stands with moist poor and moist relatively poor forest site conditions, according to the forest inventory, although in fact there are fresh poor and fresh relatively poor forest site conditions (Meshkova and Bobrov 2018).

\section{Conclusions}

For 2010-2019, the forest-covered area of the analysed forest enterprises of Polissya has changed insignificantly. However, the area of Scots pine forests and its proportion in the forest-covered area has significantly decreased in most of the analysed forest enterprises, which may be a direct consequence of pine forests' mortality caused by bark beetles.

The change for 2010-2019 in the distribution both by the trophotops and by hygrotops of the entire forested area, the area of all stands with Scots pine in species composition and pure Scots pine forests is not statistically significant. However, in the assessment in 2019, the proportion of stands in the moist types of forest sites slightly increased, and the proportion of fresh ones decreased. It may be the result of the stands' mortality in the driest sites after an outbreak of bark beetles.

For 2010-2019, a greater decrease in the proportion of Scots pine forest area in the dry poor, fresh poor and dry relatively poor forest site conditions $\left(A_{1}, A_{2}\right.$ and $B_{1}$, respectively) was found in the western direction.

The noted decrease in the foci areas of foliage browsing insects in Polissya in 2010-2012 compared to 2000-2002 could be associated with a decrease in the most preferred stands, namely the poorest and driest types of forest site conditions.

\section{ReferenCes}

Andreieva, O.Y., Boliukh, O.G. 2019. The outbreaks of Common Pine Sawfly (Diprion pini L.) in the forest fund of Zhytomyr region (in Ukrainian). Scientific Bulletin of UNFU, 29 (7), 84-89. DOI: https://doi. org/10.15421/40290717

Andreieva, O.Y., Guzii, A.I., Vyshnevskyi, A.V. 2018. Spread of bark beetles foci in pine stands of Rivne Polissya (in Ukrainian). Scientific Bulletin of UNFU, 28 (3), 14-17. DOI: https://doi. org/10.15421/40280302

Andreieva, O.Yu., Vyshnevskyi, A.V., Boliukh, S.V. 2019. Population dynamics of bark beetles in the pine forests of Zhytomyr region (in Ukrainian). Scientific Bulletin of UNFU, 29(8), 31-35. DOI: https:// doi.org/10.36930/40290803

Andreieva, O., Korma, O., Zhytova, O., Martynchuk, I., Vyshnevskyi, A. 2020. Beetles and nematodes associated with wither Scots pines. Central European Forestry Journal, 66 (1), 49-59. DOI: https://doi. org/10.2478/forj-2020-0001

Anonimous. 2019. Information yearbook on the activation of dangerous exogenous geological processes on the territory of Ukraine according to the monitoring of EGP. Kyiv; State Service of Geology and Subsoil of Ukraine, State Research and Production Enterprise 'State Information Geological Fund of Ukraine'.

Björkman, C., Bylund, H., Nilsson, U., Nordlander, G., Schroeder, M. 2015. Effects of new forest management on insect damage risk in a changing climate. Climate change and insect pests. CABI, UK, 248-266.

Borodavka, V., Borodavka, O., Getmanchuk, A., Bortnik, T., Kychylyuk, O. 2017. The modern phytosanitary condition of pinewood forests in Western Polissya and their large-scale withering: analytical reference (in Ukrainian). Scientific Bulletin of the National University of Life and Environmental Sciences of Ukraine. Series: Arboriculture and Ornamental Horticulture, 266, 126-139. 
Buzun, V.O., Turko, V.M., Siruk, Y.V. 2018. Book of Zhytomyr Forests: Historical and Economic Essay (in Ukrainian). O.O. Evenok, Zhytomyr, Ukraine.

Colombari, F., Battisti, A., Schroeder, L.M., Faccoli, M. 2012. Life-history traits promoting outbreaks of the pine bark beetle Ips acuminatus (Coleoptera: Curculionidae, Scolytinae) in the south-eastern Alps. European Journal of Forest Research, 131, 553-561. DOI: https://doi.org/10.1007/s10342-011-0528-y

Colombari, F., Schroeder, M.L., Battisti, A., Faccoli, M. 2013. Spatio-temporal dynamics of an Ips acuminatus outbreak and implications for management. $A g$ ricultural and Forest Entomology, 15, 34-42. DOI: https://doi.org/10.1111/j.1461-9563.2012.00589.x

Hammer, O., Harper, D.A. T., Ryan, P.D., 2001. PAST: paleontological statistics software package for education and data analysis. Palaeontologia Electronica, 4, 1-9.

Hentschel, R., Möller, K., Wenning, A., Degenhardt, A., Schröder, J. 2018. Importance of ecological variables in explaining population dynamics of three important pine pest insects. Frontiers in Plant Science, 9, 1667. DOI: https://doi.org/10.3389/fpls.2018.01667

Jaime, L., Batllori, E., Margalef-Marrase, J., Navarro, M.Á.P., Lloret, F. 2019. Scots pine (Pinus sylvestris L.) mortality is explained by the climatic suitability of both host tree and bark beetle populations. Forest Ecology and Management, 448, 119-129. DOI: https://doi.org/10.1016/j.foreco.2019.05.070

Kosunen, M., Kantola, T., Starr, M., Blomqvist, M., Talvitie, M., Lyytikäinen-Saarenmaa, P. 2017. Influence of soil and topography on defoliation intensity during an extended outbreak of the common pine sawfly (Diprion pini L.). IForest. 10, 164-171. DOI: 10.3832/ifor2069-009 (access on 19 November 2016).

Meshkova, V. 2006. Rating of forest plots preferences for foliage browsing insects. In: Possible limitation of decline phenomena in broadleaved stands (ed.: T.Oszako, S.Woodward). IBL, Warsaw, 125-134.

Meshkova, V.L. 2009. Seasonal development of the foliage browsing insects (in Russian). Novoe slovo, Kharkov.

Meshkova, V.L. 2019. Decline of pine forest in Ukraine with contribution from bark beetles: causes and trends (in Russian). Proceedings of the St. Petersburg Forest Technical Academy, 228, 312-335. DOI: https://doi.org/10.21266/20794304.2019.228.312-335

Meshkova, V.L., Bobrov, I.O. 2018. Pine bark beetle in the stands of Novgorod-Siversky Polissya. PlanetaPrint, Kharkiv, Ukraine.

Meshkova, V.L., Borysenko, O.I. 2017. GIS-based prediction of the foliage browsing insects' outbreaks in the pine stands of the SE "Kreminske FHE" (in Ukrainian). Proceedings of the Forestry Academy of Sciences of Ukraine, 15, 12-18. DOI: http://fasu. nltu.edu.ua, https://doi.org/ 411714

Meshkova, V.L., Borysenko, O.I., Pryhornytskyi, V.I. 2018. Forest site conditions and other features of Scots pine stands favorable for bark beetles. Proceedings of the Forestry Academy of Sciences of Ukraine, 16, 106-114. DOI: https://doi. org/10.15421/411812

Meshkova, V., Nazarenko, S., Kolienkina, M. 2019. Diprion pini L. (Hymenoptera, Symphyta, Diprionidae) population dynamics in the Low Dnieper region. Folia Forestalia Polonica, Series A - Forestry, 61 (1), 22-29. DOI: https://doi.org/10.2478/ ffp-2019-0002

Migunova, Ye.S. 1993. Forests and forest lands (Quantitative evaluation of interactions) (in Russian). Moscow, Ecology.

Mikhovich, A.I., Fedets I.F. 1965. Change in forest growing conditions under the influence of drainage in Polesie of the Ukrainian SSR (in Russian). Forestry and Forest Melioration, 3, 29-35.

Shvidenko, A., Buksha, I., Krakovska, S., Lakyda, P. 2017. Vulnerability of Ukrainian forests to climate change. Sustainability, 9 (7), 1152. DOI: https://doi. org/10.3390/su9071152

Siitonen, J. 2014. Ips acuminatus kills pines in southern Finland. Silva Fennica, 48 (4), article id 1145. DOI: http://dx.doi.org/10.14214/sf.1145

Wermelinger, B., Rigling, A., Schneider, M.D., Dobbertin, M. 2008. Assessing the role of bark- and woodboring insects in the decline of Scots pine (Pinus sylvestris) in the Swiss Rhone valley. Ecological Entomology, 33, 239-249. DOI: https://doi. org $/ 10.1111 / \mathrm{j} .1365-2311.2007 .00960 . x$ 